5. Кислюк Л. П. Словотвірна номінація в сучасній українській мові: система - узус - ідіолект : дис. ... д-ра. філол. наук : 10.02.01. Київ, 2018. 616 c. URL : http://shron1.chtyvo.org.ua/Kysliuk_Larysa/Slovotvirna_ nominatsiia_v_suchasnii_ukrainskii_movi_systema_uzus_idiolekt.pdf (дата звернення: 02.07.2020).

6. Ковалик I. І. Вчення про словотвір : вибрані праці. / Упорядник та автор передмови Василь Грещук. - Івано-Франківськ-Львів: Місто НВ, 2007. -404 c.

7. Літературна норма i мовна практика : монографія / С. Я. Єрмоленко та ін. ; за ред. С. Я. Єрмоленко. Київ, 2013. 320 с.

8. Нариси з основоцентричної дериватології / В. В. Грещук та ін. ; за ред. В. В. Грещука. Івано-Франківськ : Місто НВ, 2007. 348с.

9. Смола О. Віват, життя! Літературна Украӥна. 2017. 02 лютого. C. $8-9$.

10. Тлумачний словник української мови / уклад. Т. В. Ковальова, Л. П. Коврига. Харків : Синтекс, 2002. 672 с.

11. Шкляр В. М. Маруся : роман. Харків : Книжковий Клуб «Клуб Сімейного Дозвілля». 2014. 384 с.

DOI https://doi.org/10.30525/978-9934-588-90-7-7

\title{
ВТРУЧАННЯ РАДЯНСЬКОЇ ВЛАДИ У ВНУТРІШНЮ БУДОВУ УКРАЇНСЬКОЇ МОВИ (НА ПРИКЛАДІ СКЛАДНИХ ПРИКМЕТНИКІВ)
}

\author{
Коца Р. О. \\ кандидат філологічних наук,
} науковий співробітник відділу історії украӥнської мови та ономастики Інститут украӥнської мови Національної академії наук України м. Київ, Україна

На початку 30-х pp. XX ст. політика українізації остаточно припиняється, хоча формально вона ніколи не була скасована. Для цієї справи Й. Сталін направляє в Україну П.П. Постишева, основним гаслом культурної політики якого було усунення штучних бар'єрів між українською та російською націями і культурами. Починається боротьба проти «націоналізму» й «шкідництва» в мовознавстві. 
У 1933 р. український правопис, затверджений 6 вересня 1928 р. М. Скрипником, істотно змінили, оскільки він «був скерований на штучний відрив української мови від тої мови, що нею говорять багатомільйонні маси українських робітників і селян, на штучний відрив української мови від мови російської» [7, с. 108]. 6 квітня 1933 р. наказом нового керівництва Наркомосу України було організовано комісію під головуванням А. Хвилі для перевірки роботи на мовному фронті. Наприкінці цього ж місяця відбулися нарада 3 питань національної політики в ЦК КП(б)У та засідання створеної Комісії НКО, на яких виступив нарком освіти А. Хвиля 3 доповіддю «Націоналістична небезпека на мовному фронті й боротьба проти неї». Попередні надбання українських мовознавців оголошено буржуазним націоналізмом, оскільки вони «широко запроваджували й пропагували свої власні граматичні, фразеологічні, стилістичні вигадки, видавали це власне робливо за «закони» української мови, намагалися підносити й прищеплювати різні забобонні вигадки й свої вподобання, як непорушні канони» [7]. Така методологія, на думку Комісії, була «у своїй суті буржуазно-націоналістична»... і «продиктувала силу термінологічних спотворень на українському мовному грунті», спричинивши «мовне шкідництво» [6, с. 15-17].

Чимало уваги Комісія приділила питанням словотвору української літературної мови. 3 української мови вилучалися не просто слова, а цілі словотвірні моделі. Проілюструємо на прикладі складних прикметників.

1. Відповідниками сучасних основ верхньо- / нижньо-, що вказують на просторову орієнтацію, на початку XX ст. виступали горішньо- / долішньо-, спідньо-, що відбито, зокрема, у словнику за редакцією А. Ю. Кримського та С. О. Єфремова: горішньощелепний (1924-1933 РУАС, 1488), долішньонімецький (1662), спідньощелепний (1662). Названі основи були вилучені з української мови директивно у $30-\mathrm{x}$ рp. ХХ ст.

2. У 1933 р. на засіданні спеціальної Комісії НКО для перевірки роботи на мовному фронті було заслухано доповідь В. Ярошенка та Г. Сабалдира «Відповідники до російських прикметників з складниками подобный, -образный, -видный» [11]. Причиною цього послугувало те, що в українській мові для визначення ознаки предметів асоціативно, за зовнішньою подібністю до інших предметів активно використовувалися похідні з суфіксами -аст(ий), -ист(ий), -уват(ий), -ат(ий). Про це явище чітко написала О. Курило в «Увагах до сучасної української літературної мови»: «Російська літературна мова, коли вона прикметником хоче означити подібність до певного речівникового поняття, додає до відповідного речівникового пня слів-наростків -подобный, -образный, - 
видный, напр, шарообразный,... Українська мова має на означення подібности свої наростки -уватий, -истий, -астий (-ястий) <..>: кулястий (зигзагообразный), вилкастий (вилообразный), діжсистий (= діжкуватий)» [2, с. 93]. У випадках, коли творення прикметника зі значенням подібності за допомогою названих суфіксів неможливе, О. Курило пропонує «дати описовий зворот: на взір чого, взором чого, нагадуючи собою що» [2, с. 93].

Доповідачі наголосили на тому, що «слова $з$ складником -подібний обминалися в словниках, очевидно, не без певної націоналістичної тенденції відмежуватися від схожості з російською мовою і культивувати своє “одмітне” [11]. Розглядаючи запропонований О. Курило суфіксальний варіант творення прикметників 3 семантикою подібності, В. Ярошенко та Г. Сабалдир зазначали, що суфікси -уватий, -астий мали й інше значення. Це, на думку авторів, призводило до сплутування семантики похідних. Тому відділ української літературної мови Науководослідчого інституту мовознавства «ухвалив не обминати в українській мові слів зі складником -подібний, дослідивши глибше питання про слова 3 -подібний і -видний в новій українській літературній мові, ліквідувати надмірне поширення суфікса -уватий, залишивши його як основний відповідник до російського суфікса -оватый» [11].

За такі «хибні настанови щодо вживання тих чи інших словотворчих формантів» [3, с. 76] О. Курило зазнала нещадної критики і в наступні роки. Зокрема П. Горецький у 1934 р., аналізуючи ії працю, писав: «Так яскраво виявляється тут бажання уживати “свої наростки" і навіть, коли тих “своїх наростків" не вистачає для мови, дається “рецепт", за допомогою якого рекомендується обминати схожість 3 російською мовою “описовим зворотом". Не кажучи про потворність таких описових зворотів» [1, с. 37-51].

3. Автори зазначеної доповіді розглянули також слова зі складниками багато- і много-. Окремої резолюції з цього питання немає, однак активне насаджування в українській мові у 30-80-і pp. ХХ ст. терміноелемента много- замість багато- для перекладу аналогічних російських слів говорить само за себе: многофазовий (1928 РУСТТ, 4; $169 ;$ 373), многошаровий (6; 169; 393), многоопорний (10), многоциліндровий (67; 169), многополюсовий (169) та ін.

Особливої критики зазнали укладачі «Російсько-українського словника» 1924-1933 рр. С. О. Сфремов та А. Ю. Кримський, які на відміну від інших тогочасних лексикографів відмовилися від термінів зі староукраїнською основою много- й, підтримуючи нові тенденції в мові, 
надавали перевагу основі багато-: багатоатомний (1924-1933 РУАС, 1090), багатовалентний (1090).

4. Поширення й закріплення у правописі 1946 р. [9, с. 30] невластивих українській мові перших числівникових основ двох-, трьох-, чотирьох-: двохактний (СУМ II, 226), трьохелектродний (СУМ Х, 307), чотирьохосьовий (СУМ ХІ, 370).

На думку радянської влади, практика $30-x$ років перекладу 3 російської мови на українську (особливо в царині термінології), що використовувала «вживання спотворених слів», «викликала зниження авторитету української мови, зводила іiі до хуторянського рівня і тому була засуджена й відкинута» [8, с. 319]. 3 огляду на це Комісія НКО постановила переглянути словники і виправити в дальших виданнях припущені в них хиби. Видавалися спеціальні бюлетені, завданням яких було «очистити українську радянську термінологію від націоналістичних перекручень; знешкодити отруйний вплив націоналістичних словників на мову літератури і преси; запровадити терміни, широковживані в сучасній українській мові» [4].

Подальший шлях розвитку української наукової мови зокрема й української літературної мови загалом визначив «принцип мінімальних розходжень» - «з двох або кількох можливих нових термінологічних варіантів перевага, як правило, віддається тому, що поширений і в інших національних мовах нашої країни, зокрема в російській» [8, с. 319].

Отже, «Мову безоглядно заганяли у вузьке річище, ... ближче до російської, накидаючи спільні мовні елементи. Численні українські слова, фразеологічні звороти й синтаксичні конструкції були заборонені» $[10$, c. 204].

\section{Лiтература:}

1. Горецький П. Націоналістичні перекручення в питаннях українського словотвору. Мовознавсто. 1934. № 1. С. 37-51.

2. Курило О. Уваги до сучасної української літературної мови. Торонто : Нові дні, 1960. 199 с.

3. Матвіяс І.Г. Дослідження з граматики сучасної української літературної мови за радянське сорокаліття. Дослідження з мовознавства в Українській РСР за сорок років / відп. ред. І. К. Білодід. Київ : Вид-во АН УРСР, 1957. С. 71-92.

4. Передмова до «Ботанічного термінологічного бюлетеня». Київ, 1935.

5. Постанова народного комісара освіти УСРР від 5-го вересня 1933 р. про «Український правопис». Українська мова у XX сторіччі: 
історія лінгвочиду. Документи і матеріали / за ред. Л. Масенко. Київ : Вид. дім Києво-Могилянська академія, 2005. С. 108.

6. Резолюція Комісії НКО в справі перевірки роботи на мовному фронті. Мовознавство. 1934. № 1. С. 15-17.

7. Резолюція Комісії НКО для перевірки роботи на мовному фронті в справі граматичній. Українська мова у XX сторіччі: історія лінгвочидуу. Документи і матеріали / за ред. Л. Масенко. Київ : Вид. дім КиєвоМогилянська академія, 2005. С. 148-152.

8. Русанівський В. Розквіт і взаємозбагачення мов соціалістичних націй. Украӥнська мова у XX сторіччі: історія лінгвочиду. Документи $i$ матеріали / за ред. Л. Масенко. Київ : Вид. дім Києво-Могилянська академія, 2005. С. 309-323.

9. Український правопис. Київ, 1946.

10. Шевельов Ю. Українська мова в першій половині двадцятого століття: стан і статус. Нью-Йорк, 1987. 295 с.

11. Ярошенко В., Сабалдир Г. Відповідники до російських прикметників з складниками -подобный, -образный, -видный. Украӥнська мова $у$ XX сторіччі: історія лінгвочиду. Документи $i$ матеріали / упор.: Л. Масенко, В. Кубайчук, О. Демська-Кульчицька. Київ : Вид. дім КиєвоМогилянська академія, 2005. С. 152-163.

DOI https://doi.org/10.30525/978-9934-588-90-7-8

\title{
МОРФОЛОГІЧНІ ВАРІАНТИ СУБ'СКТНОЇ СИНТАКСЕМИ В РЕЧЕННЯХ ІЗ КВАНТИТАТИВНИМИ ПРЕДИКАТАМИ
}

\author{
Лукаш Н. М. \\ кандидат філологічних наук, \\ асистент кафедри української мови \\ Полтавський національний педагогічний університет \\ імені В. Г. Короленка \\ м. Полтава, Украӥна
}

Семантичним центром речення, носієм основного змісту повідомлення $\epsilon$ предикат, який своїми валентними властивостями визначає склад субстанційних синтаксем у реченні. Значний за обсягом шар предикатної лексики формують предикати кількості, які посідають «найпериферійніше» місце 3-поміж інших класів предикатів, що, однак, не зменшує їхньої ролі в граматичній ієрархії сучасної української мови. 